\title{
Ectoparasites of Columbina passerina insularis (Columbiformes) in the National Zoological Park, Havana, Cuba
}

\author{
Ectoparasitas de Columbina passerina insularis (Columbiformes) no Parque \\ Zoológico Nacional, Havana, Cuba \\ Daniel González-Acuña ${ }^{1 \dagger}$ (D); Armando Cicchino²; Diana Echeverry³ (D); Karen Ardiles'; Pablo Oyarzún-Ruiz (D); \\ Sergey Mironov ${ }^{4}$; ; Lucila Moreno ${ }^{5 *}$ (1) \\ ${ }^{1}$ Laboratorio de Parásitos y Enfermedades de Fauna Silvestre, Departamento de Ciencia Animal, Facultad de Ciencias Veterinarias, \\ Universidad de Concepción, Chillán, Chile \\ ${ }^{2}$ Laboratorio de Artrópodos, Departamento de Biología, Universidad Nacional de Mar del Plata, Mar del Plata, Buenos Aires, Argentina \\ ${ }^{3}$ Facultad de Medicina Veterinaria, Universidad San Sebastián, Concepción, Chile \\ ${ }^{4}$ Zoological Institute, Russian Academy of Sciences, Universitetskaya Quay 1, Saint Petersburg, Russia \\ ${ }^{5}$ Departamento de Zoología, Facultad de Ciencias Naturales y Oceanográficas, Concepción, Chile \\ ${ }^{\dagger}$ In memoriam
}

\begin{abstract}
How to cite: González-Acuña D, Cicchino A, Echeverry D, Ardiles K, Oyarzún-Ruiz P, Mironov S, et al. Ectoparasites of Columbina passerina insularis (Columbiformes) in the National Zoological Park, Havana, Cuba. Braz J Vet Parasitol 2022; 31(1): e018521. https://doi.org/10.1590/S1984-29612021096
\end{abstract}

\begin{abstract}
Ectoparasites of 18 free-living Cuban Ground Doves, Columbina passerina insularis (Columbiformes: Columbidae), captured in the National Zoological Park, Havana, Cuba, were identified. The collected ectoparasites included two species of lice (Phthiraptera: Ischnocera): Columbicola passerinae (77.1\%), and Physconelloides eurysema (50\%), as well as four species of feather mites (Astigmata: Falculiferidae): Pterophagus lomatus (83.3\%), Byersalges talpacoti (50\%), Byersalges phyllophorus (72.2\%), and Hyperaspidacarus tridentatus (27.7\%). Pterophagus lomatus, $B$. phyllophorus, and $H$. tridentatus represent new records for Cuba.
\end{abstract}

Keywords: Phthiraptera, Acari, Columbidae, ectoparasites.

\begin{abstract}
Resumo
Foram identificados os ectoparasitas de 18 rolinhas-cinzentas de vida livre, Columbina passerina insularis (Columbiformes: Columbidae), capturadas no Parque Zoológico Nacional de Havana, Cuba. Os ectoparasitas coletados pertencem à duas espécies de piolhos (Phthiraptera: Ischnocera): Columbicola passerinae (77,1\%) e Physconelloides eurysema (50\%), bem como à quatro espécies de ácaros de pena (Astigmata: Falculiferidae): Pterophagus lomatus (83,3\%), Byersalges talpacoti (50\%), Byersalges phyllophorus (72,2\%) e Hyperaspidacarus tridentatus (27,7\%). Pterophagus lomatus, B. phyllophorus e $H$. tridentatus representam novos registros para Cuba.
\end{abstract}

Palavras-chave: Phthiraptera, Acari, Columbidae, ectoparasitas.

The Common Ground Dove, Columbina passerina (Linnaeus, 1758) (Columbiformes: Columbidae), has a wide distribution, spanning the southern United States (USA) to northeastern Brazil in South America. In all, 18 subspecies are recognized, with nine occurring in the Antilles (BirdLife International, 2020). Of these, the Cuban Ground Dove or "tojosa", Columbina passerina insularis (Ridgway, 1888), is the most widely distributed and, in Cuba, is the most common bird of the family Columbidae (Schwartz, 1970). 
Parasitological studies of $C$. passerina have previously recorded the presence of the following ectoparasites: the hippoboscid fly Microlynchia pusilla (Speiser, 1902) in Mexico (Tella et al., 2000); the feather mites Pterophagus lomatus Gaud and Barré, 1992 in Guadeloupe (Gaud \& Barré, 1992a); Byersalges phyllophorus Gaud and Barré, 1988 in Guadeloupe, Barbados, Jamaica, Dominican Republic, and Santa Lucía (Gaud \& Barré, 1988, 1992a); Byersalges talpacoti (Cerny, 1975) in Barbados, Guadeloupe, Jamaica, Puerto Rico, the USA, Santa Lucia, and Brazil (Atyeo \& Winchell, 1984; Gaud \& Barré, 1988, 1992a); and Hyperaspidacarus tridentatus Atyeo and Smith, 1983 in Brazil and the USA (Atyeo \& Smith, 1983). The lice Physconelloides eurysema (Carriker, 1903) was observed in the USA, Mexico, Salvador, the Grand Cayman Islands, Colombia, Venezuela, Panama (Canal zone), and Cuba (Price et al., 1999); Hohorstiella passerina Hill and Tuff, 1978 in Cuba (Hill \& Tuff, 1978); and Columbicola passerinae (Wilson, 1941) in the British West Indies, Colombia, Mexico, Venezuela, the Virgin Islands, the USA (Alabama and Texas), and Cuba (Clayton \& Price, 1999).

This study provides novel information on geographical distribution of ectoparasites of the Cuban Ground Dove to further contribute to the existing knowledge about the parasites of wildlife in Cuba.

In the National Zoological Park (PZN), located west of the city of Havana (Cuba), 18 Cuban Ground Doves were captured with mist nets during September and October 2007. Ectoparasites were manually extracted and placed in $70 \%$ ethanol. Subsequently, lice were cleaned in $20 \% \mathrm{KOH}$ and passed through ascending ethanol solutions (40\%, $80 \%$, and $100 \%$ ), were rinsed for $24 \mathrm{~h}$ in clove oil, and finally mounted in Canada Balsam. Feather mites were rinsed in Nesbitt solution ( $40 \mathrm{~g}$ of chloral hydrate, $25 \mathrm{~mL}$ of distilled water, and $2.5 \mathrm{~mL}$ of concentrated $\mathrm{HCl}$ ) for $72 \mathrm{~h}$ at room temperature and mounted on a permanent slide in Berlese's medium (Price et al., 2003). Identification of the lice was carried out following the methods of Clayton and Price (1999) and Adams et al. (2005). The keys and species descriptions detailed by Atyeo and Smith (1983), Atyeo and Winchell (1984), Gaud and Barré (1988, 1992a, b), and Gaud and Atyeo (1996) were used for the identification of mites. For lice, the prevalence $(P)$ was expressed as the percentage of hosts infected with 1 or more individuals of a given lice species.

In the plumage of the 18 sampled Cuban Ground Doves, 38 lice individuals (Insecta: Phthiraptera) belonging to two species, as well as feather mites representing four species of the family Falculiferidae (Acari: Astigmata), were collected.

Regarding the order Phthiraptera, both a wing louse, Co. passerinae ( $n=23 ; \mathrm{P}=77 \%)$, and a body louse, Ph. eurysema $(n=15 ; P=50 \%)$, were collected from the primary and secondary wing feathers, and body feathers, respectively (Figure 1). The prevalence of lice was similar to that reported by Valim et al. (2004) for Columbina talpacoti (Temminck, 1810) in Brazil. Lice are permanent parasites occurring on birds with approximately 5,000 described species, of which about 3,000 are known from birds, and many more remain undescribed, particularly in the Neotropics (Price et al., 2003). The genus Columbicola Ewing 1929 is one of the genera with higher number of species and has approximately 88 valid species parasitizing doves and turtledoves (Price et al., 2003; Adams et al., 2005; Bush et al., 2009). Most of these species are described from these hosts from the Old World (Clayton \& Price, 1999). The species Co. passerinae was described by Wilson (1941) from C. passerina in Auburn and Slocum (USA: Alabama), and further reported from this host by Clayton and Price (1999) in the British West Indies, Colombia, Mexico, Venezuela, the Virgin Islands, the USA (Alabama and Texas), and Cuba. This louse species was also collected from other columbids: C. talpacoti, C. inca (Lesson, 1847) (= Scardafella inca), C. minuta (Linnaeus, 1766), C. picui (Temminck, 1813), Claravis mondetoura (Bonaparte, 1856), and Cl. pretiosa (Ferrari-Pérez, 1886) (Tendeiro, 1965; Palma, 1973; Clayton \& Price, 1999; Valim et al., 2004; Coimbra et al., 2012).

The genus Physconelloides Ewing, 1927 has been described as parasitizing New World columbiforms (Tendeiro, 1987) almost exclusively. Of the 30 species and subspecies described in the genus, Price et al. (1999) retained only 13 species and described three new species. Physconelloides eurysema was reported from six avian species of the genus Columbina, including C. passerina from Cuba (Price et al., 1999; Valim et al., 2004).

Feather mites were not quantified due to their high number and the fact that they could not be fully extracted. Four species belonging to the family Falculiferidae (Astigmata: Pterolichoidea) were collected: P. lomatus (83.3\%; Figure 2a), H. tridentatus (27.7\%; Figure 2b), B. phyllophorus (72.2\%; Figure 3a), and B. talpacoti (50\%; Figure 3b). Pterophagus lomatus was described by Gaud and Barré (1992a) from C. passerina in Guadeloupe, and from C. talpacoti in Guyana. Further, it was reported from the latter host in Brazil (Valim et al., 2004). Hyperaspidacarus tridentatus was formerly reported from C. passerina in Guadeloupe and Jamaica, and from C. talpacoti in Honduras, Guyana, Mexico, USA, and Brazil (Atyeo \& Smith, 1983; Pedroso \& Hernandes, 2016). Byersalges phyllophorus was described from C. passerina (Gaud \& Barré, 1988) in Guadeloupe, and from C. talpacoti in Brazil (Moraes et al., 2011; Pedroso \& Hernandes, 2016). Byersalges talpacoti was reported from four species of columbiforms in the 

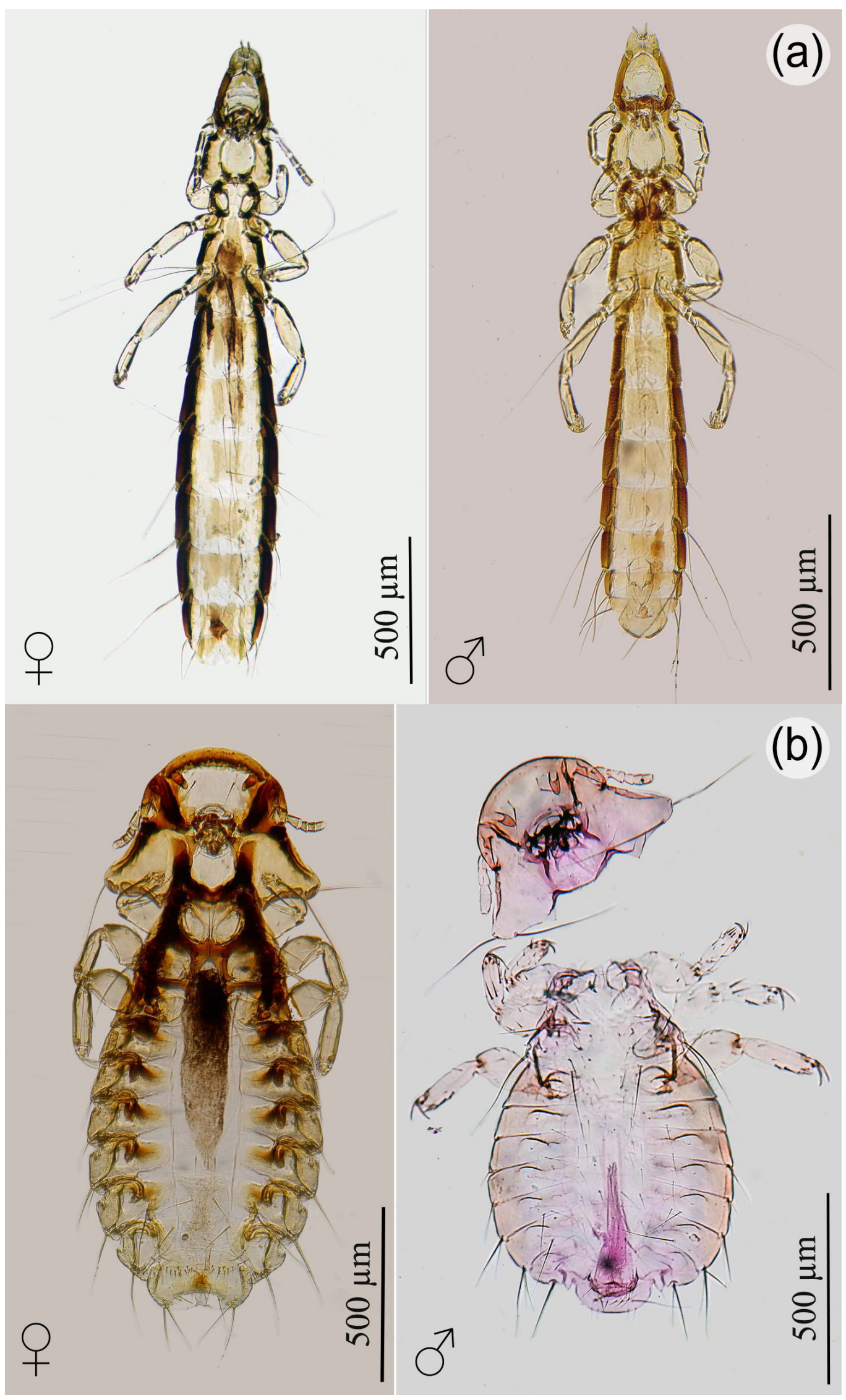

Figure 1. Lice collected from Columbina passerina insularis. (a) Dorsal view of Columbicola passerinae (wing lice), female and male, and (b) dorsal view of Physconelloides eurysema (body lice), female and male, collected from the primary and secondary wing feathers and body feathers, respectively. 


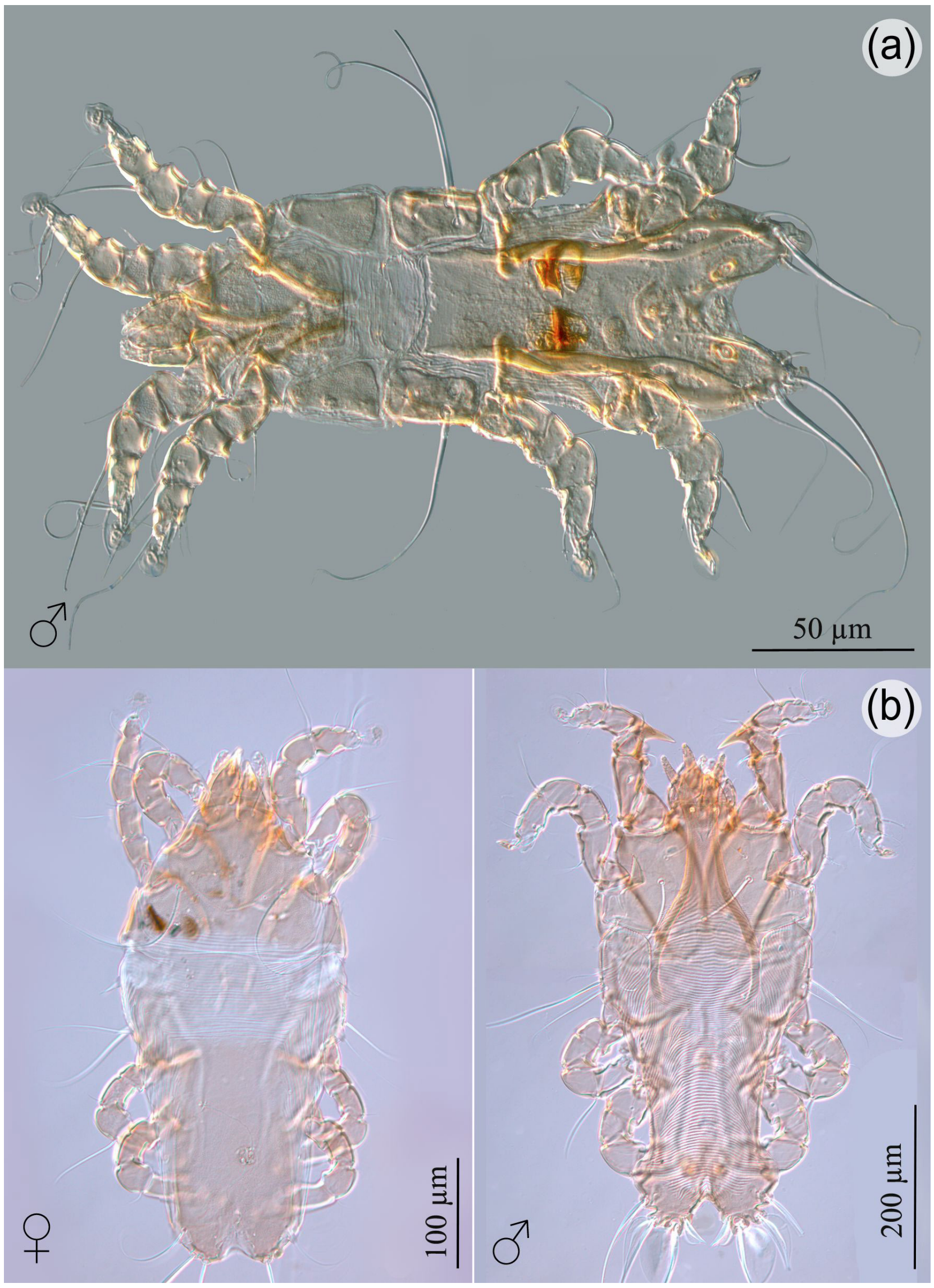

Figure 2. Mites collected from Columbina passerina insularis. (a) Dorsal view of male Pterophagus lomatus; (b) dorsal view of Hyperaspidacarus tridentatus, female and male. 


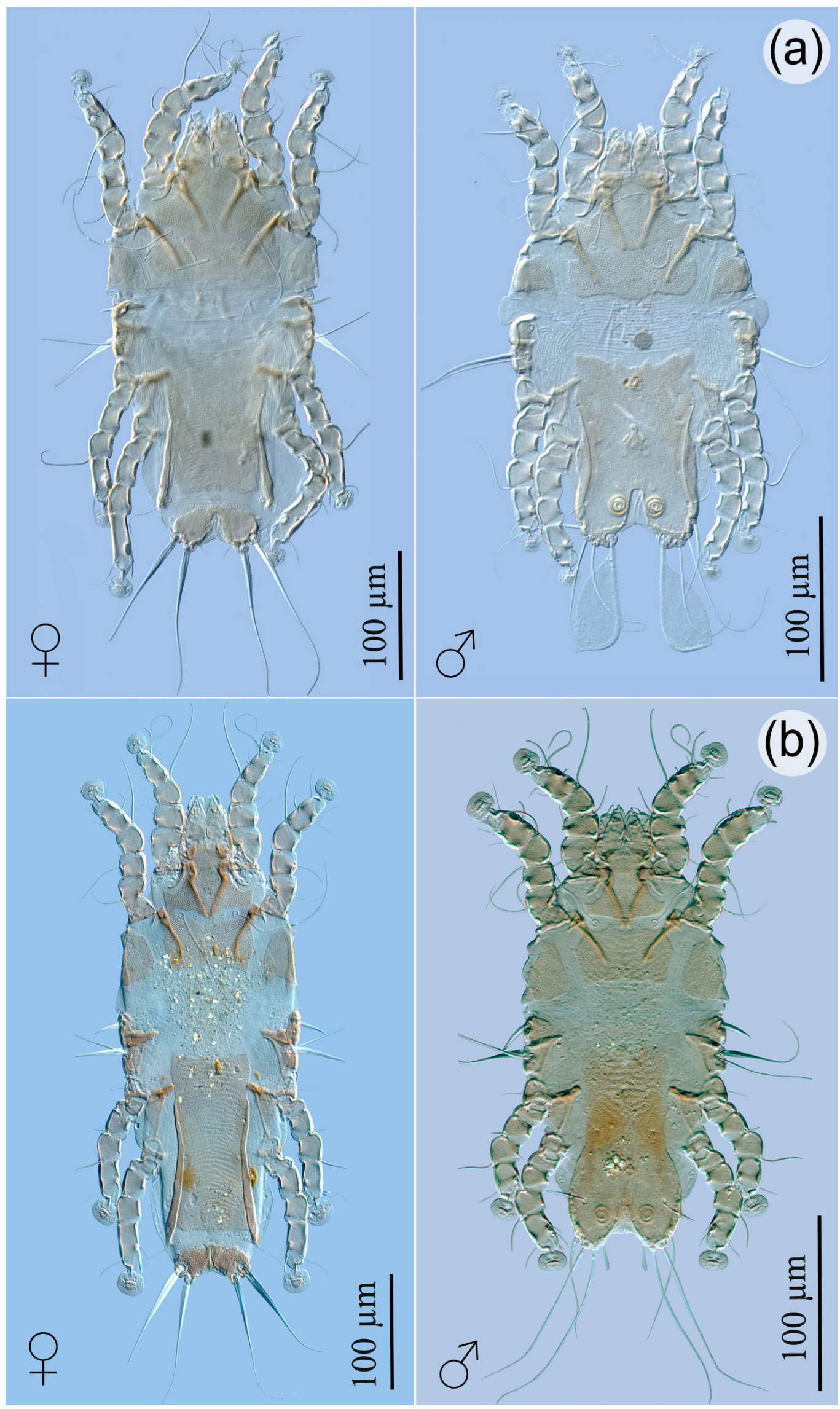

Figure 3. Mites collected from Columbina passerina insularis. (a) Dorsal view of Byersalges phyllophorus, female and male; (b) dorsal view of Byersalges talpacoti, female and male. 
New World: C. passerina in Barbados, Guadeloupe, Jamaica, Puerto Rico, Santa Lucia, and Brazil; from C. talpacoti in Colombia, Guyana, Suriname, and Brazil; from C. squammata (Lesson, 1831), Uropelia campestris (von Spix, 1825) and Zenaida auriculata (Des Murs, 1847) in Brazil; and Z. aurita (Temminck, 1810) and Z. asiatica (Linnaeus, 1758) in Cuba (Atyeo \& Winchell, 1984; Gaud \& Barré, 1992b; Valim et al., 2004; Goulart et al., 2011; Moraes et al., 2011; Pedroso \& Hernandes, 2016).

The mites $P$. lomatus, B. phyllophorus, and $H$. tridentatus collected in this study are reported for the first time in Cuba. While the lice species reported in this study, although not new reports for Cuba, reaffirm the wide distribution and close of the genera Columbicola and Physconelloides with the Columbiformes.

\section{Acknowledgements}

We are thankful to José Rivera and the Parque Zoológico Nacional, La Habana, Cuba, for access to the samples, and Juliana Vianna who reviewed the Portuguese "Resumo", and Diane Haughney who reviewed the English text.

\section{References}

Adams RJ, Price RD, Clayton DH. Taxonomic revision of Old World members of the feather louse genus Columbicola (Phthiraptera: Ischnocera), including descriptions of eight new species. J Nat Hist 2005; 39(41): 3545-3618. http://dx.doi. org/10.1080/00222930500393368.

Atyeo WT, Smith CL. New taxa of columbid (Aves) feater mites (Falculiferidae) with suprategumental shields. J Med Entomol 1983; 20(2): 207-211. http://dx.doi.org/10.1093/jmedent/20.2.207.

Atyeo WT, Winchell EJ. Byersalges, a new genus of falculiferid feather mite and host-parasite records for El Salvador. J Kans Entomol Soc 1984; 57(3): 456-459.

BirdLife International. Columbina passerina. In: IUCN, editor. The IUCN Red List of Threatened Species. Gland: IUCN; 2020.

Bush SE, Price RD, Clayton DH. Descriptions of eight new species of feather lice in the genus Columbicola (Phthiraptera: Philopteridae), with a comprehensive world checklist. J Parasitol 2009; 95(2): 286-294. http://dx.doi.org/10.1645/GE-1799.1.

Clayton DH, Price RD. Taxonomy of New World Columbicola (Phthiraptera: Philopteridae) from the Columbiformes (Aves), with descriptions of Five New Species. Ann Entomol Soc Am 1999; 92(5): 675-685. http://dx.doi.org/10.1093/aesa/92.5.675.

Coimbra MAA, Mascarenhas CS, Müller G, Brum JGW. Phthiraptera and gamasida parasites of Columbina picui (Temminck) (Columbiformes: Columbidae) in the State of Rio Grande do Sul, Southern Brazil. Braz J Biol 2012; 72(3): 583-585. http://dx.doi. org/10.1590/S1519-69842012000300022.

Gaud B, Barré N. Falculiferidae (Astigmata, Pterolichoidea) parasites des oiseaux Columbiformes des Antilles II. Le genre Falculifer. Acarologia 1992b; 33(4): 367-375.

Gaud J, Atyeo WT. Feather mites of the World (Acarina, Astigmata): the supraspecific taxa. Musée Royal de l'Afrique Centrale, Tervuren, Belgique. Tervuren: Royal Museum for Central Africa; 1996.

Gaud J, Barré N. Les genres Pterophagoides et Byersalges (Falculiferidae, Pterolichoidea) parasites plumicoles des columbidae. Acarologia 1988; 29(1): 63-71.

Gaud J, Barré N. Falculiferidae (Astigmata, Pterolichoidea) parasites des Columbiformes des Antilles. I. Genres Atyeonia, Byersalges, Hyperaspidacarus, Nanolichus, Pterophagoides et Pterophagus. Acarologia 1992a; 33(3): 273-283.

Goulart TM, Moraes DL, Prado AP. Mites associated with the eared dove, Zenaida auriculata (Des Murs, 1847), in São Paulo state, Brazil. Zoosymposia 2011; 6: 267-274. http://dx.doi.org/10.11646/zoosymposia.6.1.36.

Hill WW, Tuff DW. A review of the Mallophaga parasitizing the Columbiformes of North America north of Mexico.J Kans Entomol Soc 1978; 51(2): 307-327.

Moraes DL, Goulart TM, Prado AP. Mites associated with the ruddy ground dove, Columbina talpacoti (Temminck, 1810), in São Paulo State, Brazil. Zoosymposia 2011; 6: 275-281. http://dx.doi.org/10.11646/zoosymposia.6.1.37.

Palma R. Sobre algunos mallophaga de aves de la República Argentina (Insecta). Physis B Aires 1973; 32(85): 483-498.

Pedroso LGA, Hernandes FA. New records of feather mites (Acariformes: Astigmata) from non-passerine birds (Aves) in Brazil. Check List 2016; 12(6): 1-25. http://dx.doi.org/10.15560/12.6.2000.

Price RD, Clayton DH, Hellenthal RA. Taxonomic Review of Physconelloides (Phthiraptera: Philopteridae) from the Columbiformes (Aves), including descriptions of three new species. J Med Entomol 1999; 36(2): 195-206. 
Price RD, Hellenthal RA, Palma RL, Johnson KP, Clayton DH. The Chewing Lice: World Checklist and Biological Overview. Champaign, III.: Illinois Natural History Survey Special Publication; 2003.

Schwartz A. Subspecific variation in two species of antillean birds. Q J Fla Acad Sci 1970; 33(3): 221-236.

Tella JL, Rodríguez-Estrella R, Blanco G. Louse flies on birds of Baja California. J Wildl Dis 2000; 36(1): 154-156. http://dx.doi. org/10.7589/0090-3558-36.1.154.

Tendeiro J. Estudos sobre Mallophages. Revisão monográfica do gênero Columbicola Ewing (Ischnocera, Philopteridae). Mem Junta Investig Ultramar 1965; 32: 1-460.

Tendeiro J. Estudos sobre os Goniodídeos (Mallophaga, Ischnocera) dos Columbiformes. XXI - Novas observações sobre os géneros Saussurites Tendeiro, 1971, Physconelloides Ewing, 1927, Auricotes Kéler, 1939, Coloceras Taschenberg, 1882, Nitzschiella Kéler 1939, e Stephanius Tendeiro, 1969. Garcia de Orta. Sér Zool 1987; 12(1-2): 55-88.

Valim MP, Serra-Freire RT, Fonseca MA, Serra-Freire NM. Níveis de enzootia por ectoparasitos em amostras de rolinha [Columbina talpacoti (Temminck, 1810)] no Rio de Janeiro Brasil. Entomol Vectores 2004; 11(4): 589-598. http://dx.doi.org/10.1590/S032803812004000400003.

Wilson FH. The slender lice of American pigeons and doves with descriptions of two new species. J Parasito/ 1941; 27(3): 259264. http://dx.doi.org/10.2307/3273021. 